\title{
A comparison of alpha and beta diversity patterns of ferns, bryophytes and macrolichens in tropical montane forests of southern Ecuador
}

\author{
Nicole Mandl • Marcus Lehnert • \\ Michael Kessler • S. Robbert Gradstein
}

Received: 6 September 2009/ Accepted: 19 March 2010/Published online: 18 April 2010

(C) The Author(s) 2010. This article is published with open access at Springerlink.com

\begin{abstract}
We present a first comparison of patterns of alpha and beta diversity of ferns, mosses, liverworts and macrolichens in neotropical montane rainforests, and explore the question whether specific taxa may be used as surrogates for others. In three localities in southern Ecuador, we surveyed terrestrial and epiphytic species assemblages in ridge and slope forests in 28 plots of $400 \mathrm{~m}^{2}$ each. The epiphytic habitat was significantly richer in ferns, liverworts, and macrolichens than the terrestrial habitat; mosses, however, were primarily terrestrial. Alpha diversity of ferns and of liverworts was congruent in both habitats. Mosses were similar to ferns and liverworts only in the epiphytic habitat. Macrolichens did not share patterns of alpha diversity with any other group. Beta diversity of ferns, mosses and liverworts (lichens excluded due to low species richness) was similar in the terrestrial habitat, but not in the epiphytic habitat. Our results demonstrate that patterns of alpha diversity of the studied taxa cannot be used to predict patterns of beta diversity. Moreover, diversity patterns observed in epiphytes are different from terrestrial plants. We noted a general coincidence in species patterns of liverworts and ferns. Diversity patterns of macrolichens, in contrast, were completely independent from any other taxonomic group studied.
\end{abstract}

Keywords Biodiversity surrogates - Bryophytes - Ecuador - Epiphytic habitat · Ferns · Indicator species - Macrolichens - Liverworts - Mosses · Terrestrial habitat · Tropical montane forest

N. Mandl $(\bowtie) \cdot$ S. R. Gradstein

Department of Systematic Botany, Institute of Plant Sciences, University of Göttingen,

Untere Karspüle 2, 37073 Göttingen, Germany

e-mail: nicki_mandl@yahoo.com

M. Lehnert

Staatliches Museum Für Naturkunde, Rosenstein 1, 70191 Stuttgart, Germany

M. Kessler

Institute of Systematic Botany, University of Zürich, Zollikerstraße 107, 8008 Zürich, Switzerland 


\section{Introduction}

Tropical rain forests exemplify high species richness. While fascinating, their richness has long hampered surveys of the flora and fauna of these forests. Complete biological inventories of tropical forests do not exist. Instead, surveys have focused on selected taxa (e.g., Lawton et al. 1998; Valencia et al. 2004; Schulze et al. 2004; Nöske et al. 2008). One of the crucial questions arising from these surveys is to what degree the diversity patterns apply to other organisms, i.e., whether selected taxa can be used as surrogate taxa for others (Kessler et al., in press).

In the tropics, taxonomic surrogacy studies of plants have mainly focused on lowland forests (e.g., Duivenvoorden 1994, 1996; Tuomisto and Ruokolainen 2005), and only rarely on montane forest (La Torre-Cuadros et al. 2007). They have mainly considered only selected groups of flowering plants (but see Tuomisto and Ruokolainen 2005). Nevertheless, tropical forests often harbor rich assemblages of ferns, bryophytes (mosses, liverworts) and lichens. Especially in tropical montane rain forests, dense layers of theses organisms cover trunks and branches of trees, and sometimes also the forest floor (Gradstein and Pócs 1989; Sipman and Harris 1989). Due to their high diversity in tropical montane forest ecosystems, these groups should be considered as indicator species for the diversity of these forests.

Ferns, mosses, liverworts and lichens differ from other plant groups with respect to several ecological and physiological features including dispersal by spores rather than seeds, mobile male gametes (ferns, bryophytes), and poikilohydry (lichens, bryophytes, filmy ferns). Because of this, these taxa often have similar abiotic requirements, usually require high air humidity, and may abound in the same habitat such as humid montane forests. Field identification of bryophyte and lichen species is often difficult to determine, however, and requires time-consuming work in the laboratory. As a consequence, datasets that include all groups, ferns, bryophytes and lichens are very scarce and most studies deal with selected ones only (e.g., Gradstein et al. 2001; Kessler 2002; Kelly et al. 2004; Holz and Gradstein 2005; Tuomisto et al. 2002; Kluge et al. 2006; Ruokolainen et al. 2007). In Australian dry forests and in different vegetation types of Tasmania, vascular plant diversity was used as a potential surrogate for bryophyte and lichen diversity, respectively moss and macrofungus diversity (Pharo et al. 1999; McMullan-Fisher 2008).

In this paper, we explore alpha and beta diversity of epiphytic and terrestrial ferns, bryophytes and macrolichens in two montane rain forest of southern Ecuador, and assess the surrogacy value of each group. This is the first study on diversity and distribution patterns of ferns, bryophytes and lichens in tropical rain forest that separates between terrestrial and epiphytic taxa.

\section{Materials and methods}

\section{Study sites}

We studied primary upper montane forests on ridges and slopes at 2400-2650 m at three sites: Reserva Biológica San Francisco (RBSF), mountain pass El Tiro, and Tapichalaca Reserve, all situated in the surroundings of Podocarpus National Park in southeastern Ecuador (Fig. 1). RBSF is situated on the southern slope of the San Francisco river valley $\mathrm{N}$ of the Cordillera El Consuelo. Ranging between 1800 and $3140 \mathrm{~m}$, RBSF preserves ca. 1000 ha of montane rain forest and páramo (Beck et al. 2008). On ridges 
Fig. 1 Map of the study region and location of study sites

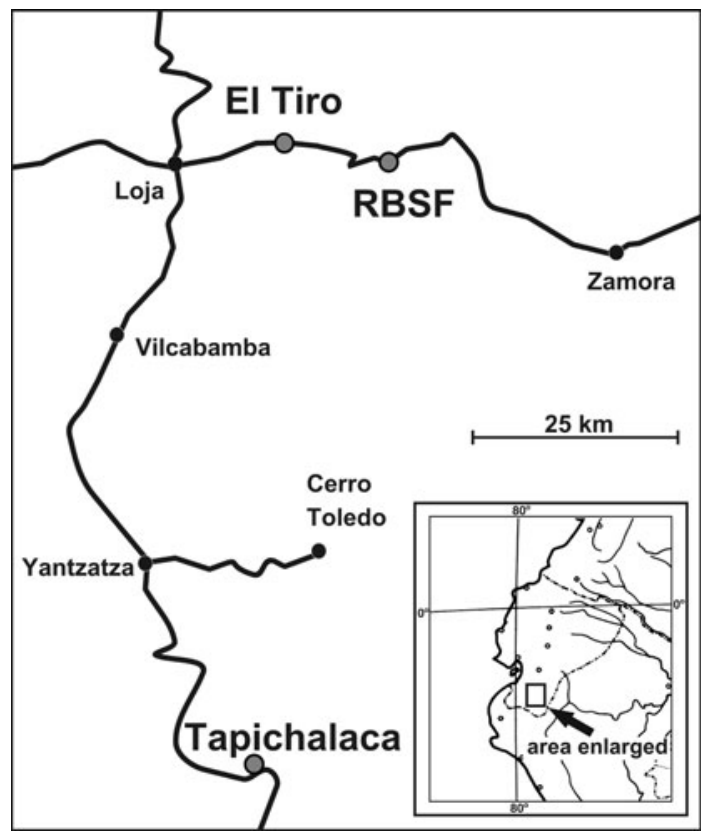

and upper slopes at 2150-2650 $\mathrm{m}$ the shrubby upper montane forest is largely dominated by a single tree species, Purdiaea nutans (Clethraceae) (Gradstein et al. 2008). Mountain Pass El Tiro is situated at ca. $2800 \mathrm{~m}$ elevation along the Loja-Zamora road, $15 \mathrm{~km} \mathrm{~W}$ of the RBSF and on the border of Loja and Zamora-Chinchipe provinces, on the crest of the cordillera. Slopes at El Tiro have a very rugged profile with many small ravines overgrown by low-statured, shrubby cloud forest with a wind-sheared canopy. The woody vegetation is diverse. Cerro Tapichalaca Reserve is situated at ca. 2000-3400 m elevation along the Loja-Zumba road in the Cordillera Real, about $90 \mathrm{~km} \mathrm{~s}$ of the town of Loja and just $\mathrm{S}$ of Podocarpus National Park. The area supports montane cloud forest and páramo (Simpson 2004). The woody vegetation is quite diverse in terms of species composition.

The climate at all three sites is cool and perhumid, with annual precipitation ranging from ca. $3000 \mathrm{~mm}$ at El Tiro to ca. $4000 \mathrm{~mm}$ at Tapichalaca and over $5000 \mathrm{~mm}$ at RBSF (Richter, 2003). Temperature maxima occasionally rise up to $25^{\circ} \mathrm{C}$ and air humidity drops down to $25 \%$ at all three locations between mid October and mid December, when monsoon-induced north-western air streams interrupt the semi-permanent easterly air flow. Soils at all three study sites are poor, acidic cambisols and gleysols ( $\mathrm{pH} 4.6-4.1)$ (Gradstein et al. 2008).

\section{Sampling methods}

Field research on the distribution of ferns, bryophytes, and macrolichens was carried out from July 2003 to January 2003 and from August 2004 to January 2004. Ten plots $(20 \mathrm{~m} \times 20 \mathrm{~m}$; six on ridges, four on slopes) were sampled at RBSF and nine plots (three on ridges, six on slopes) each at Tapichalaca and El Tiro. Inclination of ridges 
Table 1 Number of observed species in 28 plots $\left(\mathrm{S}_{\mathrm{obs}}\right)$, estimated total number of species in the study region (Chao2 estimator, $\left.\mathrm{S}_{\mathrm{est}}\right)$, sampling completeness $\left(\% \mathrm{~S}_{\mathrm{obs}}\right.$ of $\left.\mathrm{S}_{\mathrm{est}}\right)$

\begin{tabular}{lrrl}
\hline & $\mathrm{S}_{\mathrm{obs}}$ & $\mathrm{S}_{\mathrm{est}}(\mathrm{Chao} 2)$ & $\begin{array}{l}\text { Sampling } \\
\text { completeness }(\%)\end{array}$ \\
\hline Terrestrials & & & \\
Lichens & 7 & 13 & 54 \\
Liverworts & 87 & 126 & 69 \\
Mosses & 43 & 55 & 78 \\
Ferns & 116 & 147 & 79 \\
Epiphytes & & & \\
Lichens & 67 & 102 & 66 \\
Liverworts & 119 & 138 & 86 \\
Mosses & 33 & 39 & 85 \\
Ferns & 100 & 117 & 85 \\
\hline
\end{tabular}

ranged from 0 to $25 \%$ (mean 14\%), that of slopes from 30 to $50 \%$ (mean $41 \%$ ) (Table 1). Distances between plots were at least $20 \mathrm{~m}$.

Ferns were recorded as distinguishable morphospecies in the field, and number of individuals and life form (epiphyte, terrestrial) were noted for all species in each plot. Due to the small size of bryophyte and lichen taxa, their presence and abundance was estimated in subsamples. In each plot, four subsamples were taken from the terrestrial layer. To sample epiphytic assemblages, one to two trees per plot were rigged and climbed using single rope techniques (Perry 1978). Subsamples were taken from height zones, relative to the position in the host tree following (Johansson 1974). Five height zones were recognized in slope forest (trunk base, trunk, inner canopy, middle canopy, outer canopy) and only three zones in ridge forest (trunk base, inner canopy, outer canopy) due to the smaller tree size. Size of subsamples reflected habitat structure and was $30 \times 20 \mathrm{~cm}^{2}$ on soil and on trunks and in the lower canopy, and $60 \mathrm{~cm}$ long on branches and twigs in the middle and outer canopy. Voucher specimens were deposited in the herbaria of Loja (LOJA) and Quito (QCA), with duplicates in Göttingen (GOET), Berkeley (UC) and Berlin (B).

Data analysis

We calculated estimated sampling completeness for taxonomic groups using the Chao 2 richness estimator (Walther and Moore 2005) (Table 1). Calculations were done separately for epiphytic and terrestrial species, and for ridge and slope forests.

We used additive partitioning (Wagner et al. 2000; Crist et al. 2003; Gering et al. 2003) to assess mean species richness (=alpha) at different spatial scales. Alpha 1 referred to all subsamples, alpha 2 to each of 28 plots, alpha 3 to habitat type (per site); alpha 4 to study site, and alpha 5 to total richness. Beta diversity was expressed as the difference between the levels of alpha diversity, as follows: beta $1=$ alpha 2 -alpha 1 ; beta $2=$ alpha 3 -alpha 2; beta 3 = alpha 4-alpha 3 (Wagner et al. 2000; Crist et al. 2003).

We used Mantel analyses to calculate the relationship between species richness of the different taxonomic groups, and between species turnover. We estimated similarities between species assemblages with the Sørensen index (Bray-Curtis index), which also takes into account species abundances (Magurran 2004). All Mantel analyses were conducted with PCOrd 4.5 (Mc Cune and Mefford 1999) applying 9,999 randomization runs. 


\section{Results}

\section{Alpha diversity}

In total, we identified 446 species in our four study groups, of which 127 species were terrestrial, 190 epiphytic, and 129 shared between both habitats. For the terrestrial habitat, we recorded 256 species, with species richness per group varying greatly, ranging between 7 macrolichen species and 116 fern species (Table 1). The epiphytic habitat was richer in species with a total of 319 species. Liverworts and especially lichens (67 species) were more specious in the epiphytic than in the terrestrial habitat, as opposed to mosses and ferns sampling completeness ranged from $54 \%$ for terrestrial lichens to $86 \%$ for epiphytic liverworts, and was higher for epiphytes than for terrestrial taxa (Table 1). Within both habitats, sampling completeness was highest for mosses and ferns, and lowest for lichens.

Patterns of species richness at each site varied strongly between taxonomic groups (Fig. 2), with the exception of liverworts and ferns. The latter two resembled each other in
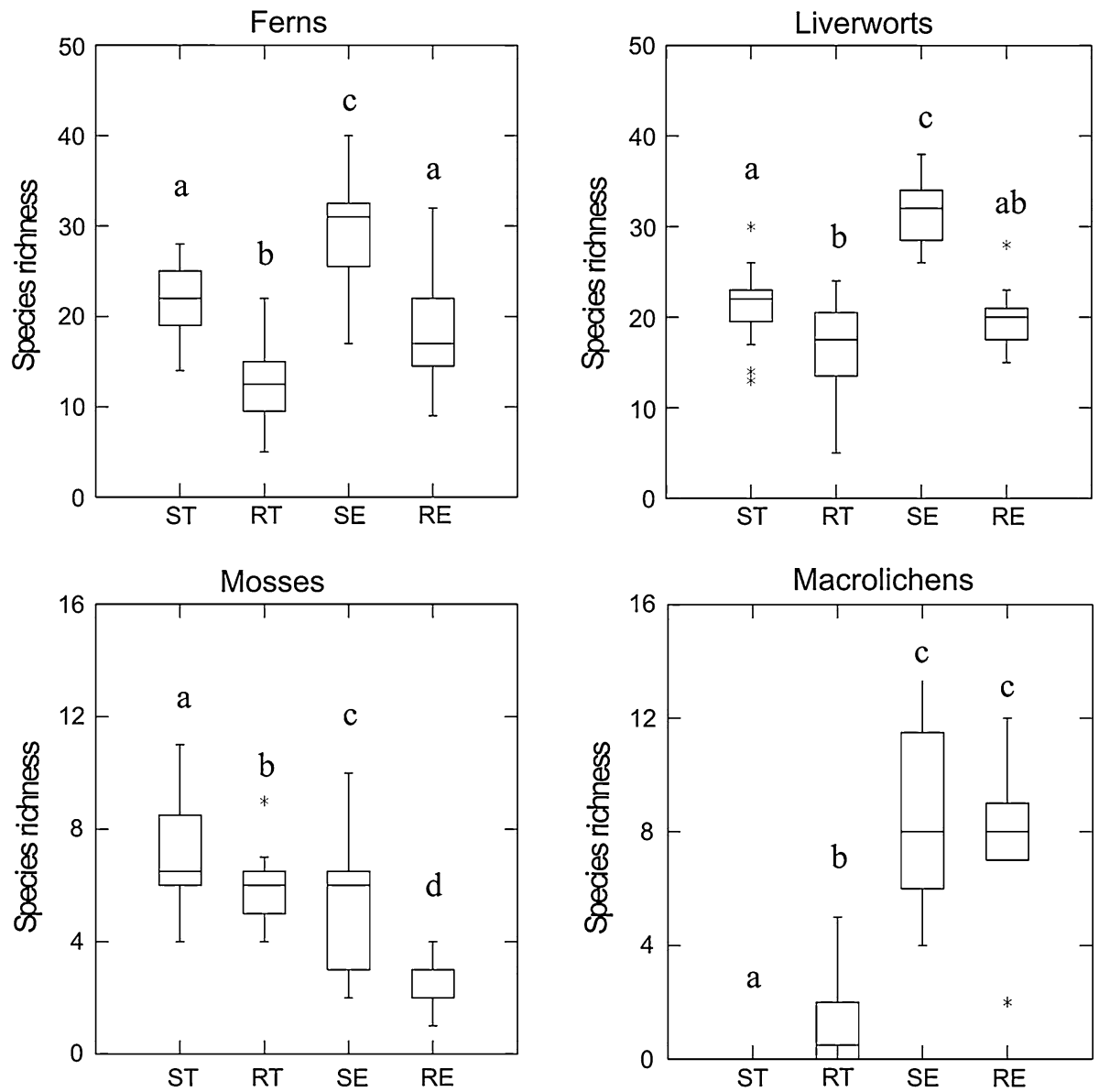

Fig. 2 Species richness of four study groups in different habitat types ( $S T$ slopes, terrestrial, $R T$ ridges, terrestrial, $S E$ slopes, epiphytic, $R E$ ridges, epiphytic). Lower case letters designate statistically different means (ANOVAs with post-hoc Tukey tests) 
Table 2 Correlations ( $\mathrm{R}$ values) between the four study groups of $\mathrm{E}$ epiphytic and $\mathrm{T}$ terrestrial species richness per plot

\begin{tabular}{|c|c|c|c|c|c|c|}
\hline & \multicolumn{2}{|c|}{ Lichens } & \multicolumn{2}{|c|}{ Liverworts } & \multicolumn{2}{|l|}{ Mosses } \\
\hline & $\mathrm{E}$ & $\mathrm{T}$ & $\mathrm{E}$ & $\mathrm{T}$ & $\mathrm{E}$ & $\mathrm{T}$ \\
\hline Ferns & 0.28 & -0.32 & $0.64 * *$ & $0.53 * *$ & $0.54 *$ & 0.21 \\
\hline Lichens & & & 0.16 & -0.24 & 0.16 & 0.02 \\
\hline Liverworts & & & & & $0.53 * *$ & 0.15 \\
\hline
\end{tabular}

Values obtained by Mantel analyses. * $P<0.05$, ** $P<0.01$

species richness per plot and their patterns of alpha diversity were similar in different habitat types. In both forest types, the epiphytic habitat was significantly richer in ferns, liverworts and lichens. Mosses were the only primarily terrestrial group. Mostly, species richness declined from slopes to ridges, with the exception of terrestrial lichens, which were absent on slopes.

The comparison of differences in alpha diversity revealed that epiphytic fern species richness was positively related to that of epiphytic liverworts and mosses $(R=0.64)$, and liverwort richness to mosses $(\mathrm{R}=0.54)$. However, we found no correlations with epiphytic lichens (Table 2). For terrestrials, only fern and liverwort species richness were significantly correlated to each other. Lichens showed slightly negative correlations with liverworts and completeness $(\mathrm{R}=0.87, P=1)$.

\section{Beta diversity}

Additive partitioning of species on the plot level revealed strongly differing patterns between the taxonomic groups, but similar patterns for epiphytes and terrestrials (Fig. 3). Ferns were the only group with a significant difference in the relative species richness for the two habitat types $(\mathrm{t}=4.84, P<0.0001)$. The plot level (alpha 2$)$ of the terrestrial habitat only yielded $12 \%$ of regional species richness, as compared to $25 \%$ in the epiphytic habitat. Additive patterns of species richness for terrestrial macrolichens were not representative due to the very low sampling completeness. Overall, epiphytes showed less variation on the regional scale than terrestrials (interesting!).
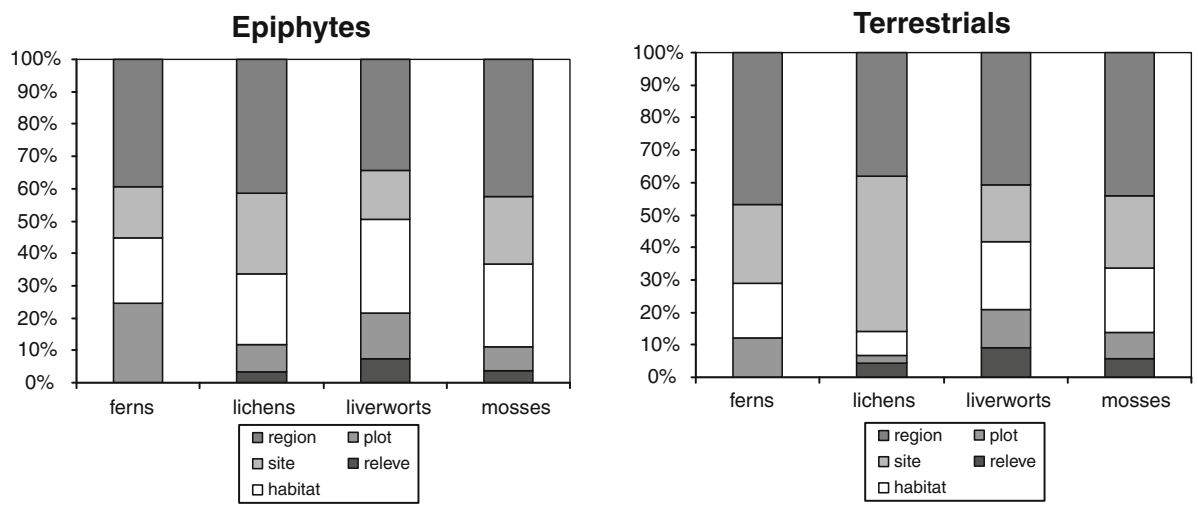

Fig. 3 Mean percentage of species found in a single subsamples, forest- or habitat type relative to the total number of species found in the study region 
Table 3 Correlations (R values) between similarity matrices of Sørensen's (Bray Curtis) index of epiphytic (E) and terrestrial (T) species compositions per plot between the four study groups

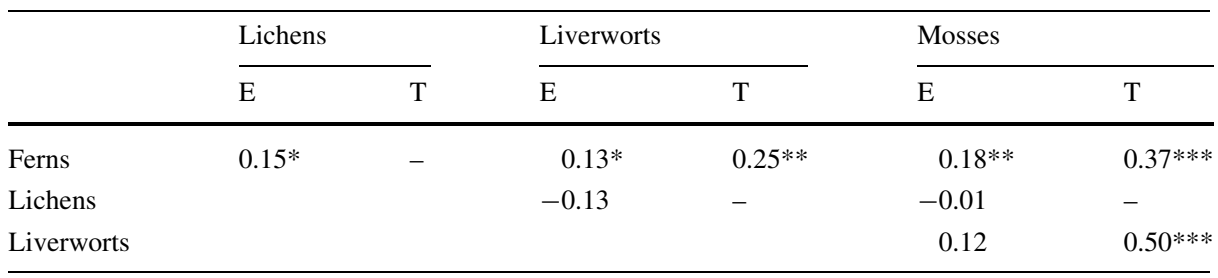

$* P<0.05, * * P<0.01, * * * P<0.001$

The Mantel test of Sørensen's indices among taxonomic groups showed significant positive correlations for nearly all groups (lichens excluded) in the terrestrial habitat, whereas only very low correlations were found in the epiphytic habitat (Table 3). The only significant correlation of lichens was with epiphytic ferns.

\section{Discussion}

Forest structure and microclimate have been identified as principal drivers of diversity of ferns, bryophytes and lichens in tropical forests (Richards 1984; Sipman and Harris 1989; Wolseley and Aguirre-Hudson 1997; Holz and Gradstein 2005; Sporn et al. 2009) For terrestrial ferns, in addition, soil characters play an important role (Kluge et al. 2006). This is the first study that compares patterns of alpha and beta diversity among mosses, liverworts, ferns, and lichens in a tropical montane forest. We also separated epiphytic and terrestrial assemblages as well as forests occurring on ridge and slope because of the different environmental conditions of these habitats.

Alpha diversity

The epiphytic habitat was significantly richer in species than the terrestrial habitat. The taxonomic groups varied in their occurrence in the different habitat types. Whereas mosses were most species-rich in the terrestrial habitat, liverworts, ferns and lichens were most diverse in the epiphytic habitat. Slope forests were generally richer in species than ridges forests. We presume that this pattern is linked to differences in structure between the two forest types. Probably, the higher trees in slope forests provide more varied and more favorable microhabitat conditions as well as more space for different species to coexist (Mandl et al. 2008), (unpubl.data).

Overall, on average only $5 \%( \pm 31 \% \mathrm{SD})$ of the variance in species richness of one taxonomic group could be predicted by species richness of another. Considering only the epiphytic habitat, this value increased to $15 \%( \pm 20 \%)$. However, these mean values conceal a high level of variation. Patterns of alpha diversity were highly congruent for ferns, liverworts, and mosses in the epiphytic habitat $\left(\mathrm{R}^{2}=0.28-0.41\right)$, and for ferns and liverworts to a lesser degree in the terrestrial habitat $\left(\mathrm{R}^{2}=0.28\right)$. Thirty two percentage of variance in epiphytic species richness of a given group was explained by other taxa (lichens omitted). In contrast, macrolichens did not show significant correlations of species richness with any other group. 
These results concur with patterns observed in coastal lowland forests of eastern Australia (Pharo et al. 1999), but they contradict results from forests of the Azores and in Indonesia in which no correlations were found among bryophytes, macrolichens, and vascular plant cover (Kessler et al, in press; Gabriel and Bates 2005). These studies, however, did not separate liverworts from mosses, nor between epiphytic and terrestrial species. Overall, numerous studies have found that patterns of alpha diversity between different higher level taxa show only limited correlation (e.g., Lawton et al. 1998; Schulze et al. 2004; Tuomisto and Ruokolainen 2005; McMullan-Fisher 2008).

\section{Beta diversity}

The variability of beta diversity as revealed by additive partitioning showed that species turnover is highly dependent the spatial scale. Generally, we found more variation in species richness between taxonomic groups within smaller spatial scales (plot) than on the regional scale. Nevertheless, by adding all species of one taxonomic group of one study site, we recorded only 55-65\% of regional species richness, with the tendency of higher proportions in the epiphytic habitat. This marked regional differentiation is noteworthy bearing in mind that our study taxa disperse by spores and are usually widespread, occurring well beyond the range spanned by our study sites (Gradstein et al. 2007; Kürschner and Parolly 2007; Lehnert et al. 2007; Nöske et al. 2007). Causes for this regional differentiation may involve slight climatic and geological differences between the three study sites (Gradstein et al. 2008) as well as stochastic dispersal and extinction events (Wolf 1994).

Ferns showed greater differences between terrestrial and epiphytic patterns at the plot level than any other study group. Although in the terrestrial habitat, ca. $12 \%$ of total diversity was occurred in sampling one plot, this amount was more than doubled in the epiphytic habitat. The majority of terrestrial ferns are relatively large (e.g., Cyatheaceae, Dryopteridaceae) compared to the majority of epiphytic taxa (e.g., Hymenophyllaceae, Polypodiaceae), which may explain the lower density of terrestrial fern species on the relatively small plots.

Correlations of beta diversity among our plant groups (lichens not included due to low species richness) were higher in the terrestrial than in the epiphytic habitat, and most pronounced for mosses and liverworts. Overall, congruence of beta diversity patterns among study groups was lower than that of alpha diversity. This implies that at least for our studied taxa, the use of an indicator group as a surrogate for others is more applicable for species richness than for community composition. This finding contrasts with studies among vascular plants in lowland Amazonia (Tuomisto and Ruokolainen 2005; Barlow et al. 2007) as well as vascular plants and bryophytes in Indonesia (Kessler et al, in press), where patterns of beta diversity were more predicable than those of alpha diversity.

Comparing patterns of alpha and beta diversity, correlations of alpha diversity were stronger in the epiphytic habitat, whereas correlations of beta diversity were stronger in the terrestrial habitat. The differing distribution of spatial heterogeneity in these two habitats may explain this pattern. The epiphytic habitat is predominately formed by mature canopy trees, all structured similarly, with stem base, trunk, inner branches, middle branches and outer twigs (Johansson 1974). Variation in habitat conditions are distributed vertically, so by sampling all height zones within a single tree, we accounted for most of the microhabitat variability of a site. In contrast, the terrestrial habitat consists of a mosaic of microhabitats influenced by microtopography, geology, soil, vegetation cover, inclination, and the amount of decaying wood. These microhabitats are scattered within a given forest 
habitat over distances that exceed the size of individual plots. In our small plot sizes, we were likely to miss out on some of the ecological variability within the terrestrial habitat.

Nevertheless, if spatial heterogeneity of the epiphytic habitat was distributed within a smaller scale, we should also expect significantly higher alpha diversities for all taxonomic groups. However, this is only true for ferns, which we have attributed to the differential size between terrestrial and epiphytic species. Thus, the conspicuous differences in alpha and beta diversity between the epiphytic and terrestrial habitats remain unknown.

\section{Conclusions}

Despite their commonalities in ecology and reproductive biology, the four investigated groups, ferns, mosses, liverworts and lichens do not share universal patterns for alpha nor beta diversity. Their response to environmental gradients as quantified in different forest and habitat types cannot easily be generalized. Furthermore, diversity patterns for epiphytes and terrestrials are distinct and should be treated separately. Ferns and liverworts show most similar patterns of alpha and beta diversity, and are most likely to work as surrogates for one another. In contrast, diversity patterns of macrolichens are completely independent from those of the other taxonomic groups studied.

Acknowledgments We thank Michael Burghardt, Jörn Hentschel, Harald Kürschner, Nicole Nöske, Gerald Parolly, Elena Reiner-Drehwald, and Harrie J. M. Sipman for help with species identifications. The authors are also grateful to Nalini M. Nadkarni for useful comments on the manuscript and for linguistic corrections. This study was funded by the German Research Foundation (DFG, project FOR 402-A4).

Open Access This article is distributed under the terms of the Creative Commons Attribution Noncommercial License which permits any noncommercial use, distribution, and reproduction in any medium, provided the original author(s) and source are credited.

\section{References}

Barlow JT, Gardner A, Araujo IS, Ávila-Pires TC, Bonaldo AB, Costa JE, Esposito MC, Ferreira LV, Hawes J, Hernandez MIM, Hoogmoed MS, Leite RN, Lo-Man-Hung NF, Malcolm JR, Martins MB, Mestre LAM, Miranda-Santos R, Nunes-Gutjahr AL, Overal WL, Parry L, Peters SL, Ribeiro-Junior MA, da Silva MNF, da Silva Motta C, Peres CA (2007) Quantifying the biodiversity value of tropical primary, secondary, and plantation forests. Proc Nat Acad Sci USA 104:18555-18560

Beck E, Bendix J, Kottke I, Makeschin F, Mosandl R (eds) (2008) Gradients in a tropical mountain ecosystem of Ecuador. Ecol Stud 198:1-525

Crist TO, Veech JA, Gering JC, Summerville KS (2003) Partitioning species diversity across landscapes and regions: a hierarchical analysis of a, b, and g diversity. Am Nat 162:734-743

Duivenvoorden JF (1994) Vascular plant species counts in the rain forests of the middle Caquetá area, Colombian Amazonia. Biodivers Conserv 3:685-715

Duivenvoorden JF (1996) Patterns of tree species richness in rain forests of the middle Caquetá area, Colombia, NW Amazonia. Biotropica 28:142-158

Gabriel R, Bates JW (2005) Bryophyte community composition and habitat specificity in the natural forests of Terceira, Azores. Plant Ecol 177:125-144

Gradstein SR, Pócs T (1989) Bryophytes. In: Lieth H, Werger MJA (eds) Tropical rain forest ecosystems. Ecosystems of the world 14A. Elsevier, Amsterdam, pp 311-325

Gradstein SR, Griffin D, Morales MI, Nadkarni NM (2001) Diversity and habitat differentiation of mosses and liverworts in the cloud forest of Monteverde, Costa Rica. Caldasia 23:203-212

Gradstein SR, Bock C, Mandl N, Nöske N (2007) Bryophyta: hepaticae. In: Liede-Schumann S, Breckle SW (eds) Provisional checklist of flora and fauna of the San Francisco valley and its surroundings (Reserva Biológica San Francisco, Province Zamora-Chinchipe, southern Ecuador). Ecotrop Monogr 4:69-87 
Gradstein SR, Kessler M, Lehnert M, Abiy M, Mandl N, Makeschin F, Richter M (2008) Vegetation, climate and soil of the unique Purdiaea forest of southern Ecuador. Ecotropica 14:15-26

Holz I, Gradstein SR (2005) Cryptogamic epiphytes in primary and recovering upper montane oak forests of Costa Rica-species richness, community composition and ecology. Plant Ecol 178:89-109

Johansson D (1974) Ecology of vascular epiphytes in West African rain forest. Acta Phytogeogr 59:1-123

Kelly DL, O'Donovan G, Feehan J, Murphy S, Drangeid SO, Marcano-Berti L (2004) The epiphyte communities of a montane rain forest in the Andes of Venezuela: patterns in the distribution of the flora. J Trop Ecol 20:643-666

Kessler M (2002) Environmental patterns and ecological correlates of range-size among bromeliad communities of Andean forests in Bolivia. Bot Rev 68:100-127

Kessler M, Abrahamczyk S, Bos M, Buchori D, Putra DD, Gradstein S., Höhn P, Kluge J, Orend F, Pitopang R, Saleh S, Schulze CH, Sporn SG, Steffan-Dewenter I, Tjitrosoedirdjo SS, Tscharntke T (in press) Alpha and beta diversity of plants and animals along a tropical land-use gradient. Ecol Appl

Kluge J, Kessler M, Dunn R (2006) What drives elevational patterns of diversity? A test of geometric constraints, climate, and species pool effects for pteridophytes on an elevational gradient in Costa Rica. Glob Ecol Biogeogr 15:358-371

Kürschner H, Parolly G (2007) Bryophyta: musci. [In: Liede-Schumann S, Breckle SW (eds), Provisional checklist of flora and fauna of the San Francisco valley and its surroundings (Reserva Biológica San Francisco, Province Zamora-Chinchipe, southern Ecuador). Ecotrop Monogr 4:89-100

La Torre-Cuadros MA, Herrando-Pérez S, Young K (2007) Diversity and structural patterns for tropical montane and premontane forests of central Peru, with an assessment of the use of higher-taxon surrogacy. Biodivers Conserv 16:2965-2988

Lawton J, Bignell DE, Bolton B, Bloemers GF, Eggleton P, Hammond PM, Hodda M, Holt RD, Larsen TB, Mawdsley NA, Stork NE, Srivastava DS, Watt AD (1998) Biodiversity inventories, indicator taxa and effects of habitat modification in tropical forest. Nature 391:72-76

Lehnert M, Kessler M, Salazar LI, Navarette H, Werner FA, Gradstein SR (2007) Pteridophytes. In: LiedeSchumann S, Breckle SW (eds), Provisional checklist of flora and fauna of the San Francisco valley and its surroundings (Reserva Biológica San Francisco, Province Zamora-Chinchipe, southern Ecuador). Ecotrop Monogr 4:59-68

Magurran AE (2004) Measuring biological diversity. Blackwell, Oxford

Mandl N, Lehnert M, Gradstein SR, Kessler M, Abiy M, Richter M (2008) The unique Purdiaea nutans forest of southern Ecuador-abiotic characteristics and cryptogamic diversity. Ecol Stud 198:275-280

Mc Cune B, Mefford MJ (1999) PC-ORD Multivariate analysis of ecological data. Version 4. MjM Software Design, Gleneden Beach

McMullan-Fisher SJM (2008) Surrogates for cryptogam conservation: associations between mosses, macrofungi, vascular plants and environmental viables. Dissertation, University of Tasmania

Nöske NM, Mandl N, Sipman HJM (2007) Lichenes. In: Liede-Schumann S, Breckle SW (eds) Provisional checklist of flora and fauna of the San Francisco valley and its surroundings (Reserva Biológica San Francisco, Province Zamora-Chinchipe, southern Ecuador). Ecotrop Monogr 4:101-117

Nöske NM, Hilt N, Werner F, Brehm G, Fiedler K, Sipman HJ, Gradstein SR (2008) Disturbance effects on diversity of epiphytes and moths in a montane forest in Ecuador. Basic and Appl Ecol 9:4-12

Perry DR (1978) A method of access into the crowns of emergent and canopy trees. Biotropica 10:155-157

Pharo EJ, Beattie AJ, Binns D (1999) Vascular plant diversity as a surrogate for bryophyte and lichen diversity. Conserv Biol 13:282-292

Richards PW (1984) The ecology of tropical forest bryophytes. In: Schuster RM (ed) New manual of bryology, vol 2. The Hattori Botanical Laborartory, Nichinan, pp 1233-1270

Richter M (2003) Using epiphytes and soil temperature for eco-climatic interpretations in Southern Ecuador. Erdkunde 57:161-181

Ruokolainen K, Tuomisto H, Macía MJ, Higgins MA, Yli-Halla M (2007) Are floristic and edaphic patterns in Amazonian rain forests congruent for trees, pteridophytes and Melastomataceae? J Trop Ecol 23:13-25

Schulze CH, Waltert M, Keßler PJA, Pitopang R, Shahabuddin Veddeler D, Mühlenberg M, Gradstein SR, Leuschner C, Steffan-Dewenter I, Tscharntke T (2004) Biodiversity indicator groups of tropical landuse systems: comparing plants, birds, and insects. Ecol Appl 14:1321-1333

Simpson N (2004) Saving threatened plants and birds in the Andes of Ecuador. Plant Talk 37:17-21

Sipman HJM, Harris RC (1989) Lichens. In: Lieth H, Werger MJA (eds) Tropical rain forest ecosystems. Ecosystems of the world 14A. Elsevier, Amsterdam, pp 303-309

Sporn SG, Bos MM, Hoffstätter-Müncheberg M, Kessler M, Gradstein SR (2009) Microclimate determines community composition but not richness of epiphytic understory bryophytes of rainforest and cacao agroforest in Indonesia. Funct Plant Biol 36:171-179 
Tuomisto H, Ruokolainen K (2005) Environmental heterogeneity and the diversity of pteridophytes and Melastomataceae in western Amazonia. Biol Skr 55:37-56

Tuomisto H, Ruokolainen K, Poulsen AD, Moran RC, Quintana C, Canas G, Celi J (2002) Distribution and diversity of pteridophytes and Melastomataceae along edaphic gradients in Yasuni National Park, Ecuadorian Amazonia. Biotropica 34:516-533

Valencia R, Foster RB, Villa G, Condit R, Svenning J-C, Hernández C, Romoeroux K, Losos E, Magard E, Balslev H (2004) Tree species distribution and local habitat variation in the Amazon: large forest plot in eastern Ecuador. J Ecol 92:214-229

Wagner HH, Wildi O, Ewald KC (2000) Additive partitioning of plant species diversity in an agricultural mosaic landscape. Landsc Ecol 15:219-227

Walther B, Moore JL (2005) The concept of bias, precision and accuracy, and their use in testing the performance of species richness estimators, with a literature review of estimator performance. Ecography 28:815-829

Wolf JHD (1994) Factors controlling the distribution of vascular and non-vascular epiphytes in the northern Andes. Vegetation 112:15-28

Wolseley PA, Aguirre-Hudson B (1997) The ecology and distribution of lichens in tropical deciduous and evergreen forests of northern Thailand. J Biogeogr 24:327-343 